We are grateful to Journal of Chemical Research for permission to publish the full paper on line.

\title{
Synthesis of novel carboxylated benzoxazolylcoumarins
} Lígia M. Rodrigues*, X. H. Luan, Ana M.A.G. Oliveira and Ana M.F. Oliveira-Campos Centro de Química, IBQF, Departamento de Química, Universidade do Minho, 4710-057 Braga, Portugal

Six novel coumarins containing carboxylic ester or acid groups were prepared. The compounds were characterised by the usual methods. In a few cases the fluorescence data were obtained.

Coumarins are a family of compounds that have been studied extensively for their practical applications, ${ }^{1}$ as textile dyes, ${ }^{2}$ optical brighteners, laser dyes, sensitisers in phototherapy, biological labels. Coumarin derivatives have been also used in making fluorogenic enzyme substrates. ${ }^{3}$

Disperse dyes containing an electron-donating group, such as N,N-diethylamino, and an heterocyclic residue in position 3 are widely used as optical brighteners for polyester, polyamide and polyvinyl chloride plastics. ${ }^{4}$

Several 7-hydroxycoumarins substituted in position 3 are efficient laser dyes and the lasing range is amplified if there is an heterocyclic ring at this position. ${ }^{5}$

Recently, we have been working with compounds containing S, N or O heterocycles linked to a benzoxazole..$^{6-8}$ In this paper we report the synthesis of coumarinyl-benzoxazole derivatives with carboxylic groups on the benzoxazole moiety (Fig. 1). This type of compound would enlarge the scope of the potential applications for industrial ${ }^{9}$ or biological purposes. ${ }^{3}$

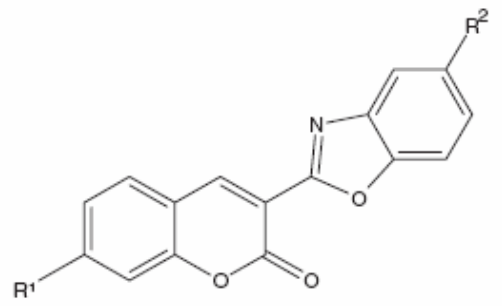

$$
\begin{aligned}
& \text { 1a R } \mathrm{R}^{1}=\mathrm{HR}^{2}=\mathrm{CO}_{2} \mathrm{Et} \\
& \text { 1b R } \mathrm{R}^{1}=\mathrm{H} \mathrm{R}^{2}=\mathrm{CO}_{2} \mathrm{H} \\
& \text { 2a R } \mathrm{R}^{1}=\mathrm{OH} \mathrm{R} \mathrm{R}^{2}=\mathrm{CO}_{2} \mathrm{Et} \\
& \text { 2b R } \mathrm{R}^{1}=\mathrm{OH} \mathrm{R} \mathrm{R}^{2}=\mathrm{CO}_{2} \mathrm{H} \\
& \text { 3a R } \mathrm{R}^{1}=\mathrm{NEt}_{2} \mathrm{R}^{2}=\mathrm{CO}_{2} \mathrm{Et} \\
& \text { 3b R } \mathrm{R}^{1}=\mathrm{NEt}_{2} \mathrm{R}^{2}=\mathrm{CO}_{2} \mathrm{H}
\end{aligned}
$$

Fig. 1 Structures of compounds 1-3.

Three different methods were used in attempts to improve the yield in the preparation of compounds 1-3 (Schemes 1-3). The final cyclisation in method 1 was achieved in polyphosphoric acid as described by Carpignano. ${ }^{10}$ When a carboxylated coumarin was heated with 3-amino-4hydroxybenzoic acid at high temperature with PPA (Scheme1, $\left.\mathrm{R}^{2}=\mathrm{CO}_{2} \mathrm{H}\right)$, decarboxylation was 
observed thus giving low to moderate yields (Table 1, $\mathbf{1 b}, \mathbf{2} \mathbf{b}$ and $\mathbf{3 b}$ ). To overcome this problem ethyl ortho-aminobenzoate was prepared and used in the same way, (Scheme $1, \mathrm{R}^{2}=\mathrm{CO}_{2} \mathrm{Et}$ ). The final compounds were obtained in partially hydrolysed form. An extreme case was one of the preparations of 3a, where the final mixture contained only a small amount of the product. After purification the ester, 3a, was obtained in $10 \%$ yield still contaminated with the acid (the hydrolysis occurred during purification) and the main product of this reaction (40\%) was 7-N,Ndiethylcoumarin.

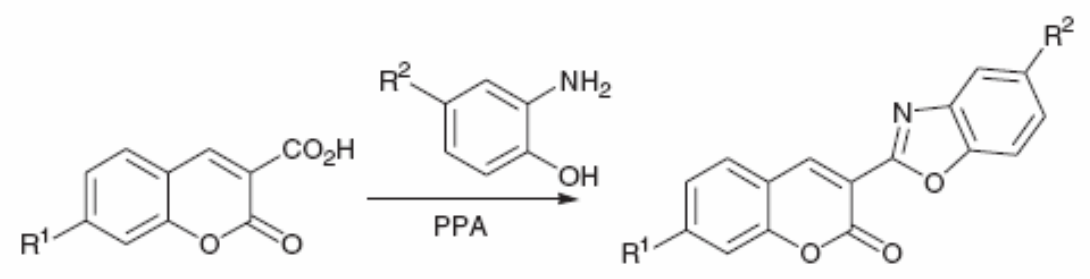

Scheme 1

Table 1 Yields, purification details and physical properties of dyes

\begin{tabular}{|c|c|c|c|c|}
\hline Dye & Method & Yield (\%) ${ }^{a}$ & Purification solvent $^{\mathrm{b}}$ & Appearance \\
\hline $1 \mathbf{a}$ & 1 & $\begin{array}{l}56 \\
64^{c}\end{array}$ & B & Ligh gray solid \\
\hline $1 b$ & $\begin{array}{l}3 \\
1\end{array}$ & 7 & $\overline{\mathrm{B}}$ & Light yellow solid \\
\hline $2 a$ & $\begin{array}{l}1 \\
2\end{array}$ & $\begin{array}{l}10 \\
36\end{array}$ & A & Yellow solid \\
\hline $2 \mathbf{b}$ & 1 & $\begin{array}{l}32 \\
77^{\mathrm{d}}\end{array}$ & $\mathrm{C}$ & Yellow solid \\
\hline За & 1 & 23 & B & Dark yellow solid \\
\hline $3 \mathbf{b}$ & $\begin{array}{l}1 \\
2\end{array}$ & $\begin{array}{l}42 \\
50\end{array}$ & $\begin{array}{l}\mathrm{D} \\
\mathrm{D}^{\mathrm{e}}\end{array}$ & $\begin{array}{l}\text { Dark yellow solid } \\
\text { Light brown solid }\end{array}$ \\
\hline
\end{tabular}

A second method was used in which the suitable 2-cyanomethylbenzoxazole was prepared first and then reacted with the corresponding ortho-hydroxybenzaldehyde (Scheme 2). ${ }^{5,11}$ The yield for compound 2a improved by this method. Attempts to purify compound $\mathbf{3 b}$ further led to decomposition mainly to the 7-N,N-diethylcoumarin-3-carboxylic acid possibly due to hydrolysis of the oxazole ring. ${ }^{12}$ 


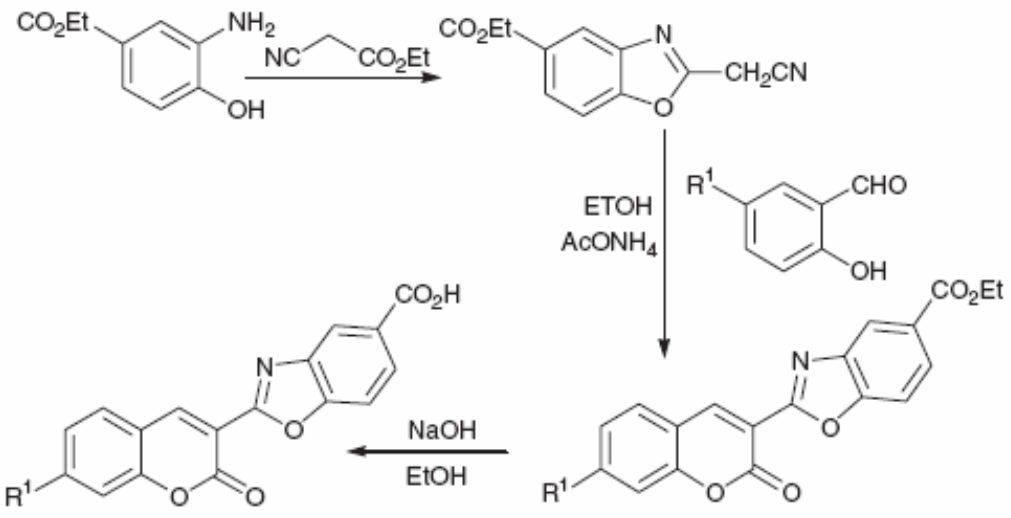

Scheme 2

The third route started from the same coumarin as method 1 . This was activated by reaction with ethylchloroformate to the mixed anhydride and then this was reacted with the corresponding substituted ortho-aminophenol (Scheme 3). The crude amide which was formed was then heated with PPA in order to obtain the final compound. This method was used for the preparation of 1a, but the final mixture contained both $\mathbf{1 a}$ and $\mathbf{1 b}$ in 1:1 proportion, as deduced by NMR. (Table 1).

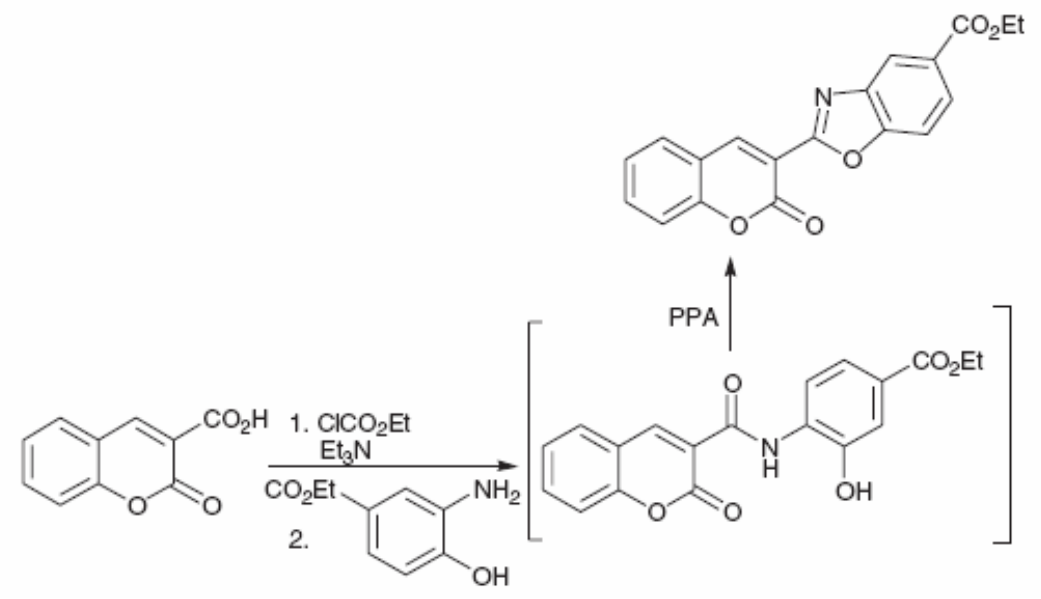

Scheme 3

All the compounds were characterised by spectroscopic methods. The fluorescence spectra were obtained except for compound $\mathbf{3 b}$. It was not possible to obtain $\mathbf{3 b}$ in a pure enough form for fluorescence analysis (Table 2). 
Table 2 Spectroscopic data for fluorescent compounds

\begin{tabular}{|c|c|c|c|c|}
\hline \multicolumn{5}{|c|}{ UV-Visible ${ }^{\mathrm{a}}$} \\
\hline & \multicolumn{2}{|c|}{ Absorption } & \multicolumn{2}{|c|}{$\lambda \max (\mathbf{n m})$} \\
\hline & $\lambda \max (\mathbf{n m})$ & $\varepsilon\left(\mathrm{mol}^{-1} / \mathrm{dm}^{3} / \mathrm{cm}^{-1}\right)$ & Excitation & Emission \\
\hline $1 \mathbf{a}$ & 347 & 11554 & 350 & 439 \\
\hline $1 b$ & 352 & 11444 & 350 & 450 \\
\hline $2 \mathbf{a}$ & 447 & 23504 & 447 & 475 \\
\hline $2 b$ & 445.5 & 19398 & 447 & 476 \\
\hline За & 429 & 24000 & 450 & 490 \\
\hline
\end{tabular}

${ }^{a} A b s o r p t i o n$ and fluorescence spectra were measured in ethanol.

Examination of Table 2 shows that the introduction of a donating group in the coumarin ring gave a bathochromic shift in the absorption spectra (100 nm for 2a and $82 \mathrm{~nm}$ for 3a).

Fig. 2 shows the absorption and emission spectra of $\mathbf{1 b}$, which was the compound that gave the larger Stokes shift in this study (Table 2).

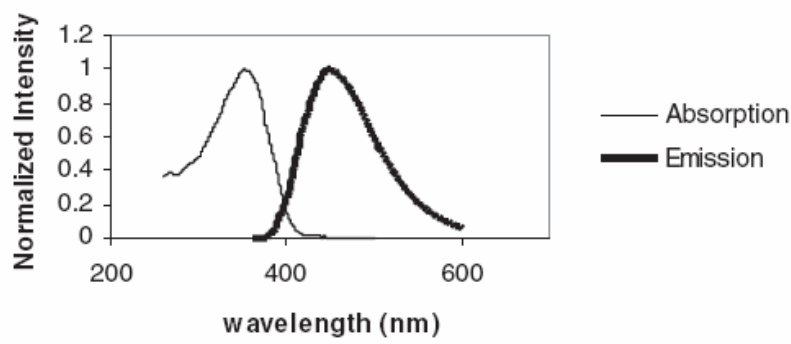

Fig. 2 Absorption and emission spectra of $\mathbf{1 b}$ in ethanol.

\section{Experimental}

The infrared spectra were determined in Nujol and on a Perkin Elmer FTIR-1600 or Shimadzu UV3101 PC spectrometers. ${ }^{1} \mathrm{H}$ NMR spectra were obtained on a Varian Unity Plus Spectrometer at 300 $\mathrm{MHz}$, and $\mathrm{Me}_{4} \mathrm{Si}$ or the solvent peak was used as reference. Electron impact mass spectra were recorded on a Unicam GC/MS 120 by direct insertion.

FAB and high resolution mass spectra were run on a VG Ultima HRMS or an Auto Spec E spectrometer. UV-visible spectra were determined on a Hitachi U-2000. Fluorescence spectra were determined on a SPEX FLUOROLOG-2 analyser, with double monochromator and an emission Xenon lamp of 4450 watts. Elemental analyses were carried out on a Leco CHNS 932 instrument. All melting points were measured on a Gallenkamp apparatus and are uncorrected. TLC was carried out on plates coated with $0.25 \mathrm{~mm}$ thick silica gel $60 \mathrm{~F}_{254}$. Column chromatography was performed on silica gel $(<230 \mathrm{mesh})$. 
Synthesis of carboxylated chromen-3-yl-benzoxazole: general procedures

\section{Method 1}

A mixture of coumarin $(0.5 \mathrm{mmol})$, the suitable ortho-aminophenol $(2.5 \mathrm{mmol})$ and polyphosphoric acid $(10 \mathrm{~g})$ was heated at $160^{\circ} \mathrm{C}$ for $1.5-2$ hours. After cooling, water $(40 \mathrm{ml})$ and then a $5 \mathrm{M} \mathrm{NaOH}$ solution $(20 \mathrm{ml})$ were added. The precipitate was filtered, washed with water and dried at $60^{\circ} \mathrm{C}$. After analysis by TLC (thin layer chromatography) it was purified by crystallisation or chromatography.

\section{Method 2}

A mixture of ethyl cyanoacetate $(5 \mathrm{mmol})$ and the corresponding ortho-aminophenol ( $5 \mathrm{mmol})$ was heated at $180^{\circ} \mathrm{C}$ in an oil bath for 2 hours. After cooling ammonium acetate $(5 \mathrm{mmol})$, ethanol (5 $\mathrm{ml}$ ) and the corresponding hydroxybenzaldehyde $(5 \mathrm{mmol})$ were added and the mixture was refluxed for 30 minutes. A mixture of water and ethanol $(15 \mathrm{ml}, 2: 1)$ was added and the precipitate was filtered.

In the preparation of $\mathbf{3 b} \mathrm{DMF}$ was used as solvent. After cooling water was added and the precipitate was filtered.

Preparation of 2-(2'-Oxo-2'H-chromen-3'-yl)-benzoxazole-5-carboxylic acid ethyl ester (1a) by Method 3

To an ice cold suspension of coumarin-3-carboxylic acid $(1 \mathrm{mmol})$ in acetone $(10 \mathrm{ml})$ ethyl chloroformate $(0.15 \mathrm{ml}, 1.2 \mathrm{mmol})$ and triethylamine $(0.164 \mathrm{ml}, 1.2 \mathrm{mmol})$ were added. The initially orange suspension turned light yellow and a white solid precipitated after 10 minutes. The triethylamine hydrochloride was filtered off and, the appropriate ortho-aminophenol (1 mmol) was added to the filtrate. The mixture was stirred at room temperature overnight. The yellow suspension was evaporated to dryness and a yellow solid (the amide) was obtained which was pure by TLC. PPA (ca $5 \mathrm{~g}$ ) was added to the amide and the mixture was heated at $150-170{ }^{\circ} \mathrm{C}$ for 4 hours. After cooling, water was added, a reddish-orange solution was formed and then $5 \mathrm{M} \mathrm{NaOH}$ solution was added until the $\mathrm{pH}$ was 7 . A yellow oil separated that solidified overnight. This solid was purified by crystallisation.

2-(2'-Oxo-2'H-chromen-3'-yl)-benzoxazole-5-carboxylic acid ethyl ester (1a): The compound does not melt below $\left.350{ }^{\circ} \mathrm{C} . \delta_{\mathrm{H}}(\text { Acetone-d })_{6}\right) 1.44\left(3 \mathrm{H}, \mathrm{t} J 7.0 \mathrm{~Hz}, \mathrm{CH}_{2} \mathrm{CH}_{3}\right), 4.43(2 \mathrm{H}, \mathrm{q} J 7.0 \mathrm{~Hz}$, $\left.\mathrm{CH}_{2} \mathrm{CH}_{3}\right), 7.48-7.56\left(2 \mathrm{H}, \mathrm{m}, 6\right.$ ' and 8'-H), $7.84\left(1 \mathrm{H}, \mathrm{dt} J 8.0 \mathrm{~Hz}, 7^{\prime}-\mathrm{H}\right), 7.89$ (1H, d J $\left.8.8 \mathrm{~Hz}, 7-\mathrm{H}\right)$, $8.05\left(1 \mathrm{H}\right.$, dd $J 8.0$ and $\left.1.5 \mathrm{~Hz}, 5^{\prime}-\mathrm{H}\right), 8.20(1 \mathrm{H}$, dd $J 8.8$ and $1.5 \mathrm{~Hz}, 6-\mathrm{H}), 8.45(1 \mathrm{H}, \mathrm{d} J 1.5 \mathrm{~Hz}, 4-$ 
H), $9.06\left(1 \mathrm{H}, \mathrm{s}, 4\right.$ '-H). EI (m/z \%) 358( $\left.\mathrm{M}^{+}+\mathrm{Na}, 9\right) 336\left(\mathrm{M}^{+}+\mathrm{H}, 100\right) * 336 \rightarrow 308(336-328) 264(336-$ 372) $308 \rightarrow 290280$ 264. $v_{\max } 1744,1707,1607 \mathrm{~cm}^{-1}$. Calc. for $\mathrm{C}_{19} \mathrm{H}_{13} \mathrm{~N}_{2} \mathrm{O}_{5}$ 335.0794. Found 335.0782 .

2-(2'-Oxo-2'H-chromen-3'-yl)-benzoxazole-5-carboxylic (1b): The compound does not melt below $350{ }^{\circ} \mathrm{C} . \delta_{\mathrm{H}}\left(\mathrm{DMSO}^{\left.-\mathrm{d}_{6}\right)} 7.46\left(1 \mathrm{H}, \mathrm{t} J 8.0 \mathrm{~Hz}, \mathrm{H}-6\right.\right.$ '), $7.50\left(1 \mathrm{H}, \mathrm{d} J 8.0 \mathrm{~Hz}, \mathrm{H}-8{ }^{\prime}\right), 7.77(1 \mathrm{H}, \mathrm{dt} J 8.0$ and $\left.1.5 \mathrm{~Hz}, \mathrm{H}-7^{\prime}\right), 7.93$ (1H, d J 8.4 Hz, H-7), 8.02 (1H, dd J 8.0 and $1.5 \mathrm{~Hz}, \mathrm{H}-5$ '), 8.08 (1H, dd 8.4 and $1.5 \mathrm{~Hz}, \mathrm{H}-6), 8.35$ (1H, br s, H-4), $9.14(1 \mathrm{H}, \mathrm{s}, \mathrm{H}-4$ '), $13.20(1 \mathrm{H}$, very br s, COOH). EI (m/z, \%) 307(M+, 90) 279(18) 235(32) 206(10) 91(40) 73(80) 56(100). $v_{\max } 3474$ (br), 1747, 1704, $1606 \mathrm{~cm}^{-1}$ Calc. for $308.0559 \mathrm{C}_{17} \mathrm{H}_{10} \mathrm{NO}_{5}$. Found $308.0550\left(\mathrm{FAB}^{+}\right)$.

2-(7'-Hydroxy-2'-oxo-2'H-chromen-3'-yl)-benzoxazole-5-carboxylic acid ethyl ester (2a): m.p. 257$260{ }^{\circ} \mathrm{C} . \delta_{\mathrm{H}}\left(\mathrm{CDCl}_{3}\right) 1.35\left(3 \mathrm{H}, \mathrm{t} J 7.2 \mathrm{~Hz}, \mathrm{CH}_{2} \mathrm{CH}_{3}\right), 4.55\left(2 \mathrm{H}, \mathrm{q} J 7.2 \mathrm{~Hz}, \mathrm{CH}_{2} \mathrm{CH}_{3}\right), 6.79(1 \mathrm{H}, \mathrm{d} J$ $\left.1.8 \mathrm{~Hz}, 8^{\prime}-\mathrm{H}\right), 6.88\left(1 \mathrm{H}\right.$, dd $J 8.5$ and $\left.1.8 \mathrm{~Hz}, 66^{\prime}-\mathrm{H}\right), 7.84\left(1 \mathrm{H}, \mathrm{d} J 8.5 \mathrm{~Hz}, 5^{\prime}-\mathrm{H}\right), 7.90(1 \mathrm{H}, \mathrm{d} J 8.7$ Hz, 7-H), 8.05 (1H, dd J 8.5 and $1.5 \mathrm{~Hz}, 6-\mathrm{H}), 8.31$ (1H, d J $1.5 \mathrm{~Hz}, 4-\mathrm{H}), 8.99$ (1H, s, 4'-H), OH not observed). EI (m/z, \%) 351(M+, 3) 379(9) 306(6) 278(2) 250(2) 189(2) 162(4). $v_{\max } 3514-3114$ (br), 3309, 1701, $1617 \mathrm{~cm}^{-1}$. Calc. For $\mathrm{C}_{19} \mathrm{H}_{13} \mathrm{NO}_{6}$. $\mathrm{H}_{2} \mathrm{O}$ C, 61.79; H, 4.07, N, 3.79. Found C, 61.34; $\mathrm{H}, 4.56 ; \mathrm{N}, 3.87$.

2-(7'-Hydroxy-2'-oxo-2'H-chromen-3'-yl)-benzoxazole-5-carboxylic acid (2b): $1 \mathrm{M} \mathrm{NaOH}$ (1.35 ml, $1.35 \mathrm{mmol})$ was added under stirring to a soln. of compound $2 \mathrm{a}(0.315 \mathrm{~g}, 0.897 \mathrm{mmol})$ in ethanol $(15 \mathrm{ml})$ at room temperature. After stirring for 4 hours the mixture was cooled in an ice-water bath and acidified to $\mathrm{pH} 3$ with $5 \mathrm{M} \mathrm{HCl}$. After storage in the cold overnight the precipitate was collected on a filter, washed thoroughly with water and air dried to yield a brown solid $(0.224 \mathrm{~g}, 77 \%)$. Purification by PLC (ethyl acetate/light petroleum, 1:1) yielded the title compound as a yellow solid; decomposes without melting above $30{ }^{\circ} \mathrm{C}$; $\delta_{\mathrm{H}}\left(\mathrm{DMSO}_{6}\right) 6.95\left(1 \mathrm{H}, \mathrm{d} J 8.2 \mathrm{~Hz}, 6{ }^{\prime}-\mathrm{H}\right), 7.15$ $\left(1 \mathrm{H}, \mathrm{d} J 8.2 \mathrm{~Hz}, 5^{\prime}-\mathrm{H}\right), 7.32\left(1 \mathrm{H}, \mathrm{s}, 8^{\prime}-\mathrm{H}\right), 7.75(1 \mathrm{H}, \mathrm{d} J 8.2 \mathrm{~Hz}, 7-\mathrm{H}), 7.82$ (1H, d J 8.2 Hz, 6-H ), $8.90(1 \mathrm{H}, \mathrm{s}, 4-\mathrm{H}), 9.90\left(1 \mathrm{H}, \mathrm{s}, 4{ }^{\prime}-\mathrm{H}\right), 11.10(1 \mathrm{H}, \mathrm{s}, \mathrm{OH})$. The second $\mathrm{OH}$ signal is not observed. $v_{\max }$ $3408,1704,1614 \mathrm{~cm}^{-1}$. Calc. for $\mathrm{C}_{17} \mathrm{H}_{10} \mathrm{NO}_{6} 324.0508$. Found $324.0508\left(\mathrm{M}^{+}+1, \mathrm{FAB}^{+}\right)$.

2-(7'-Diethylamino-2'-oxo-2'H-chromen-3'-yl)-benzoxazole-5- carboxylic acid ethyl ester (3a): Decomposes without melting above $270{ }^{\circ} \mathrm{C} . \delta_{\mathrm{H}}\left(\mathrm{CDCl}_{3}\right) 1.20\left(6 \mathrm{H}, \mathrm{t} J 7.5 \mathrm{~Hz}, 2 \mathrm{x} \mathrm{CH}_{2} \mathrm{CH}_{3}\right), 1.42$ $\left(3 \mathrm{H}, \mathrm{t} J 7.5 \mathrm{~Hz}, \mathrm{CH}_{2} \mathrm{CH}_{3}\right), 3.50\left(4 \mathrm{H}, \mathrm{q} J 7.5 \mathrm{~Hz}, 2 \mathrm{x} \mathrm{CH}_{2} \mathrm{CH}_{3}\right), 4.40\left(2 \mathrm{H}, \mathrm{q} J 7.5 \mathrm{~Hz}, \mathrm{CH}_{2} \mathrm{CH}_{3}\right), 6.56$ $\left(1 \mathrm{H}, \mathrm{d} J 1.8 \mathrm{~Hz}, 8^{\prime}-\mathrm{H}\right), 6.68$ (1H, dd $J 8.2$ and $\left.1.8 \mathrm{~Hz}, 6^{\prime}-\mathrm{H}\right), 7.44\left(1 \mathrm{H}, \mathrm{d} J 8.2 \mathrm{~Hz}, 5^{\prime}-\mathrm{H}\right), 7.90$ (1H, d $J 9.0 \mathrm{~Hz}, 7-\mathrm{H}), 8.10$ (1H, dd $J 9.0$ and $1.5 \mathrm{~Hz}, 6-\mathrm{H}), 8.50$ (1H, d J 1.5 Hz, 4-H), 8.64 (1H, s, 4'-H). 
EI (m/z, \%) 406(6) 391(3) 363(5) 204(15) 91(22). $v_{\max } 3070,1704,1621,1602 \mathrm{~cm}^{-1}$. Calc. for $\mathrm{C}_{23} \mathrm{H}_{22} \mathrm{~N}_{2} \mathrm{O}_{5} 406.1529$. Found 406.1527.

2-(7'-Diethylamino-2'-oxo-2'H-chromen-3'-yl)-benzoxazole-5-carboxylic acid (3b): Decomposes without melting above $250{ }^{\circ} \mathrm{C} . \delta_{\mathrm{H}}\left(\mathrm{DMSO}_{6}\right) 6.60\left(1 \mathrm{H}, \mathrm{d} J 2.0 \mathrm{~Hz}, 8^{\prime}-\mathrm{H}\right), 6.80-6.88\left(1 \mathrm{H}, \mathrm{m}, 6^{\prime}-\mathrm{H}\right)$, $7.65(1 \mathrm{H}, \mathrm{d} J 9.0 \mathrm{~Hz}, 5$ '-H or 7-H), $7.70(1 \mathrm{H}, \mathrm{d} J 9.0 \mathrm{~Hz}, 5$ '-H or 7-H), $8.00(1 \mathrm{H}$, dd $J 9.0$ and 2.1 Hz, 6-H ), 8.20 (1H, d J 2.0 Hz, 4-H), $8.64(1 \mathrm{H}, \mathrm{s}, \mathrm{OH}), 8.82(1 \mathrm{H}, \mathrm{s}, 4 '-\mathrm{H})$. EI $(\mathrm{m} / \mathrm{z}, \%) 406(6)$ 391(3) 363(5) 204(15) 91(22). $v_{\max } 3378,1702,1611 \mathrm{~cm}^{-1}$. Calc. For $\mathrm{C}_{21} \mathrm{H}_{19} \mathrm{~N}_{2} \mathrm{O}_{5}$ 379.1294. Found $379.1280\left(\mathrm{M}^{+}+1, \mathrm{FAB}^{+}\right)$.

Thanks are due to FCT(Portugal) and PRAXIS XXI for project 2/2.1/QUI/44/94 and for a grant to invited Scientists (BCC/4237/96) to Dr Xin Hui Luan (on leave from Institute of Pharmacology and Toxicology, Beijing, China). To Miss Elisa Pinto for obtaining the NMR and elemental analyses data, and to Mr. Mário Rui Pereira for advice with fluorescence determinations.

\section{References}

1. X.R.M. Christie and C.-H. Lui, Dyes and Pigments, 1999, 42, 85.

2. X. Luo, X. Naiyun, L. Cheng and D. Huang, Dyes and Pigments, 2001, 51, 153.

3. C. Charitos, G. Kokotos and C. Tzougraki, J. Heterocyclic Chem., 2001, 38, 153.

4. J. Sokolowska,W. Czajkowski and R. Podsiadly, Dyes Pigments, 2001, 49, 187.

5. M.H. Elnagdi, S.O. Abdallah, K.M. Ghoneim, E.M. Ebied and K.N. Kassab, J. Chem. Res., 1997, (S) 44, (M) 375.

6. S.P.G. Costa, J. Ferreira, G. Kirsch and A.M.F. Oliveira-Campos, J. Chem. Res., 1997, (S), 314; (M) 2001.

7. P.C.A. Santos, M.M.M. Raposo, S.P.G. Costa and A.M.F. Oliveira-Campos, Adv. Colour Sci. Technol., 2002, 5, 94.

8. X.H. Luan, N.M.F.S.A. Cerqueira, A.M.A.G. Oliveira, M.M.M. Raposo, L.M. Rodrigues, P. Coelho and A.M.F. Oliveira-Campos, Adv. Colour Sci Technol., 2002, 5, 18.

9. (a) A.H.O. Karkkainen, O.E. Horni and J.T. Rantala, SPIE Proceedings, San Jose 2000, 194; (b) N.M.F.S.A. Cerqueira, L.M. Rodrigues, A.M.F. Oliveira-Campos, P.J. Coelho, L.H. Melo de Carvalho, A.Samat and R. Guglielmetti, Helv. Chim. Acta, 2003, 86, 3244.

10. P. Savarino, G. Viscardi, E. Barni, R. Carpignano, Dyes Pigments, 1988, 9, 295.

11. H. Moeller and C. Gloxhuber, C.A. 82, 170876a (Ger.Offen., 2327959; 1975).

12. J.V. Boyd, Comprehensive Heterocyclic Chemistry, ed. A.R. Katritzky and C.W. Rees, Pergamon Press, Oxford, 1984, vol. 6, p. 191. 